\title{
Kelimpahan plankton pada budidaya udang vaname (Litopenaeusvannamei) dengan kepadatan berbeda di tambak lahan pasir
}

\section{(Plankton abundance on white leg shrimp (Litopenaeus vannamei) cultivation with different stocking densities in sand land)}

\author{
Gamal M. Samadan ${ }^{*}$, Supyan ${ }^{2}$, Rovina Andriani ${ }^{3}$, Juharni ${ }^{4}$ \\ ${ }_{1 *, 3,4}$ Program Studi Budidaya Fakultas Perikanan dan Kelautan Unkhair \\ ${ }^{2}$ Program Studi Manajemen Sumberdaya Perairan Fakultas Perikanan dan Kelautan Unkhair \\ *E-mail: gmsamadan@unkhair.ac.id \\ Diterima: 4 Juni 2020; Disetujui: 2 November 2020
}

\begin{abstract}
ABSTRAK
Penelitian ini bertujuan mengestimasi kelimpahan dan kestabilan perairan tambak melalui pengukuran indek sbiologi (keanekaragaman, keseragaman dan dominansi plankton) di tambak intensif dengan kepadatan berbeda. Percobaan telah dilakukan menggunakan 9 petak tambak dengan ukuran $3 \times 4 \mathrm{~m}^{2}\left(12 \mathrm{~m}^{2}\right)$. Percobaan dirancang dalam 3 perlakuan padat tebar berbeda $\left(100,200\right.$ dan $\left.300 \mathrm{~m}^{2}\right)$ yang diulangi sebanyak 3 kali. Periode pemeliharaan udang selama 75 hari dengan mengukur indeks biologi plankton (keragaman, keseragaman dan dominansi). Pengamatan dilakukan di laboratorium terhadap kelimpahan jenis plankton dan parameter fisika-kimia air dilakukan terhadap suhu, kecerahan, $\mathrm{pH}$, salinitas dan DO setiap hari. Sedangkan nitrite, nitrat, amonia dan BOT diamati setiap dua minggu. Analisis dilakukan terhadap indeks keragaman, indeks keseragaman dan indeks dominansi plankton di tambak. Ditemukan 5 genera dan 18 spesies pada tambak lahan pasir. Kelimpahan terbanyak didapatkan pada genera Chlorophyta dan Bacillariophyta. Indeks keragaman plankton relative sama pada ketiga perlakuan $(0,11-0,35)$, indeks keseragaman sebesar 0,04-0,12 dan indeks dominansi sebesar 0,85-0,97. Indeks keragaman dan keseragaman relative rendah, meskipun demikian, indeks dominansi plankton relative stabil.
\end{abstract}

Kata kunci : Indeksbiologi, kelimpahan, plankton, tambak, vaname

Citasi : Samadan MG, Supyan, Andriani R, Juharni. 2020.Kelimpahan Plankton Pada Budidaya Udang Vaname, 3 (2) : 165 - 185

\section{ABSTRACT}

This study aims to estimate the abundance and stability of pond waters by measuring the biological index (diversity, uniformity, and plankton dominance) in intensive ponds with different densities. Experiments were carried out using 9 pond plots with a size of $3 \times 4 \mathrm{~m} 2$ (12m2). The experiment was designed in 3 different stocking density treatments $(100,200$, and $300 \mathrm{~m} 2)$ which were repeated 3 times. Shrimp rearing period for 75 days by measuring the plankton biological index (diversity, uniformity, and dominance). Observations were made in the laboratory on the abundance of plankton species and the physico-chemical parameters of water were carried out on temperature, brightness, pH, salinity, and DO every day. Meanwhile, nitrite, nitrate, ammonia, and BOT were observed every two weeks. The analysis was carried out on the diversity index, 
uniformity index, and plankton dominance index in the ponds. Five genera and 18 species were found in the sand farms. The greatest abundance was found in the genera Chlorophyta and Bacillariophyta. The plankton diversity index was relatively the same in the three treatments (0.11-0.35), the uniformity index was 0.04-0.12 and the dominance index was 0.85-0.97. The diversity and uniformity indices are relatively low, however, the plankton dominance index is relatively stable.

Keywords: Biological index, abundance, plankton, pond, vaname

\section{Pendahuluan}

Fluktuasi ekstrim berbagai parameter kualitas air pada perairan tambak pembesaran udang dapat menyebabkan penurunan kelangsungan hidup udang yang berlanjut pada penurunan produksi. Fitoplankton merupakan salah satu faktor yang mempengaruhi fluktuasi kualitas air. Produksi fitoplankton pada budidaya intensif dipengaruhi oleh keberadaan unsur hara di perairan, terutama unsur hara dari kelompok nitrogen $(\mathrm{N})$ dan fosfat $(\mathrm{P})$. Ketersediaan unsur hara pada budidaya intensif ditentukan oleh keberadaan jumlah bahan organik dan tingkat penguraiannya oleh bakteri. Bahan organik tersebut berasal dari pakan buatan yang tidak terkonsumsi (sisa pakan) dan ekskresi dari udang. Sebagaimana yang dinyatakan oleh Boyd (1990), peningkatan pemberian pakan buatan akan meningkatkan kandungan bahan organik serta unsur hara yang pada batas-batas tertentu akan meningkatkan produktifitas primer perairan.

Keberadaan plankton di perairan dapat dijadikan sebagai salah satu indikator suatu perairan karena sangat dipengaruhi oleh kualitas air. Fitoplankton merupakan indikator biologi untuk mengevaluasi kualitas dan tingkat kesuburan suatu perairan. Fitoplankton sangat diharapkan pertumbuhannya secara optimal di perairan tambak. Pengelolaan fitoplankton umumnya dilakukan dengan mengoptimalkan bahan organic serta pemupukan dan pergantian air.

Menurut Poernomo (1997), manfaat plankton pada pengelolaan tambak udang intensif yaitu saat kekeruhan karena plankton dengan nilai daya cerah perairan antara 30-40 cm justru diperlukan dan pertumbuhan plankton yang baik ditandai oleh berubahnya warna air tambak dari coklat muda hingga hijau daun muda, mutlak dipertahankan karena: 1) plankton membuat tambak menjadi teduh, sehingga udang dapat lebih aktif mencari makan di sianghari; 2) plankton nabati merupakan produsen O2 dalam air; 3) bermanfaat sebagai pakan alami udang khususnya pada awal pemeliharaan setelah penebaran benur; 4) menekan pertumbuhan klekap dan lumut di dasar tambak; dan 5) plankton nabati membantu menyerap senyawa yang sangat berbahaya bagi udang seperti ammonia, nitrit dan nitrat.

Masalah yang dihadapi dalam pengelolaan tambaku dan gintensif yang ditandai dengan menurunnya daya cerah perairan dan seringnya terjadi blooming plankton terutama karena semakin suburnya dasar tambak akibat timbunan suspensiorganik dari kotoran udang dan sisa-sisa pakan (pelet), menumpuknya sel plankton yang sudah tua dan mati serta gerakan udang yang aktif karena semakin besar. Kepadatan plankton yang berlebihan dalam perairan tambak, berbahaya bagi udang yang dibudidayakan karena: 1) saat cuaca ceraha kan terjadi produksi $\mathrm{O}_{2}$ yang berlebihan melalui proses fotosintesis. Kadar $\mathrm{O}_{2}$ yang mencapai kejenuhan $250 \%$ menimbulkan gas emboli pada jaringan daun insang udang. Karena gangguan akut pernafasan, udang biasanya mengambang di permukaan air tambak. Sebaliknya saat malam hari, akan terjadi 
kekurangan $\mathrm{O}_{2}$ karena proses respirasi oleh plankton. Persyaratan mutu air bagi tambak udang memiliki oksigen terlarut berkisar $3-10 \mathrm{mg} / \mathrm{L}$ (Poernomo, 1997).

Menurut Barnes dan Mann (1991), tingkat produksi plankton di suatu perairan dapat digunakan untuk menduga potensi produksi udang dan ikan, kondisi suatu perairan bersifat stabil atau tidak stabil dan apabila populasi plankton di suatu perairan lewat jenuh (blooming) dapat dijadikan sebagai indicator pencemaran biologis. Ekosistem suatu perairan dengan keragaman hayati yang rendah adalah tidak stabil dan rentan terhadap pengaruh tekanan dari luar dibandingkan dengan ekosistem yang memiliki keragaman hayati yang tinggi (Boyd, 1998).

Kondisi lingkungan perairan tambak yang stabil ditandai dengan keragaman plankton tinggi, jumlah individu setiap spesies tinggi dan merata serta kualitas air lingkungan tambak berada dalam kisaran yang sesuai dengan pertumbuhan organisme budidaya (Poernomo, 1997). Karena pentingnya pengelolaan fitoplankton di tambak, maka diperlukan penelitian untuk menganaliasis keragaman plankton di perairan tambak udang intensif. Tujuan penelitian untuk mengestimasi kekayaan dan kestabilan perairan tambak melalui pengukuran indeksbiologi (keanekaragaman, keseragaman dan dominansi plankton) di tambak intensif.

\section{Metode Penelitian}

\subsection{Lokasi dan Waktu}

Penelitianinidilakukanselama 3 bulandi stasiun penelitian lapangan Jurusan Perikanan Universitas Gadjah Mada, Desa Keburuhan Kabupaten Purworejo, Jawa Tengah.Analisis dan identifikasi sampel plankton dilakukan di laboratorium lapangan Central Protein Prima Purworejo.

\subsection{Bahan dan Metode}

Bahan utama yang digunakan adalah sampel air tambak udang vaname yang telah berisi plankton. Sampling dilakukan di tambak udang kepadatan tebar berbeda sebanyak 9 petak.Alat dan bahan yang digunakan untuk pengambilan sampel plankton antara lain: ember volume 10 liter, botol sampel $100 \mathrm{ml}$, plankton net ukuran $40 \mu \mathrm{m}$ dan 3-5 tetes Lugol sebagai pengawet.Seluruh sampel kemudian dibawa ke laboratorium untuk dianalisis lebih lanjut. Identifikasi sampel plankton dilakukan dengan menggunakan mikroskop dan glass object serta haemacytometer dengan metode penyapuan.

\subsection{Pengamatan dan Analisis Plankton}

Identifikasijenis plankton dilakukan di laboratorium menggunakan mikroskop yang berpedoman pada Newell dan Newell (1977), Yamaji (1976), dan Botes (2003) serta kelimpahannya menggunakan Sedgwick Rafter Counting Cell (APHA, 2005). Untuk mengetahui kekayaan dan kestabilan perairan, maka dilakukan analisis kuantitatif indeks biologi plankton meliputi perhitungan keragaman, keseragaman, dan dominansidari Shannon-Wiener (Odum, 1993; Basmi, 2000) dan formulanya sebagai berikut:

Indeks Keragaman Jenis:

$\mathrm{H}^{\prime}=$ Indeks keragaman jenis

$$
\begin{gathered}
\mathrm{H}^{\prime}=-\sum \text { pi ln pi } \\
p i=n i / N
\end{gathered}
$$

ni $=$ Jumlah individu taksake-i

$\mathrm{N}=$ Jumlah total individu

$\mathrm{pi}=\mathrm{ni} / \mathrm{N}=$ Proporsi spesies ke-i 
Indeks Keseragaman:

$\mathrm{E}=$ Indeks keseragaman jenis

$$
E=H^{\prime} / H^{\prime} \max
$$

$\mathrm{H}^{\prime}=$ Indeks keragaman jenis

$\mathrm{H}^{\prime}$ maks = Indeks keragaman maksimum

Indeks Dominansi:

$$
\mathrm{D}=(\mathrm{pi}) 2
$$

$\mathrm{D}=$ Indeks dominansi

ni $=$ Jumlah individu taksake-i

$\mathrm{N}=$ Jumlah total individu

$\mathrm{pi}=\mathrm{ni} / \mathrm{N}=$ Proporsi spesies ke-i

Peubahkualitas air yang diamati di tambakmeliputisuhu, $\mathrm{pH}$, salinitas, dan oksigenterlarut, sedangkannitrat, nitrit, amonia, fosfat, bahanorganik total, dan padat antersuspensi total dianalisis di laboratorium.

Statistik deskriptif digunakan untuk mengetahui gambar anumum dari kelimpahan, jumlah genus dan indeks biologi (keragaman, keseragaman dan dominansi) plankton serta kondisi lingkungan perairan tambak.

\section{Hasil dan Pembahasan}

Pengamatan jenis fitoplankton pada setiap petak tambak sangat bervariasi (Tabel 1). Hasil identifikasi ditemukan sebanyak 5 genus fitoplankton yang terdiri dari 18 spesies. Kelima genus tersebut adalah Chlorophyta (alga hijau)sebanyak 4 spesies, Cyanophyta (alga hijau biru) sebanyak 4 spesies, Bacillariophyta (Diatome) sebanyak 6 spesies, Dinoflagelata sebanyak 3 spesies dan Cryptophyta sebanyak 1 spesies. Chlorophyta dan Bacillariophyta (Diatome) terdapat di semua petak perlakuan, sedangkan Cyanophyta, Diniflagellata dan Cryptophy tahanya ditemukan di beberapa petak tambak dengan kepadatan berbeda. Jumlah fitoplankton terbanyak terdapat pada perlakuan $100\left(\mathrm{ekor} / \mathrm{m}^{2}\right)$ yakni sebanyak 41.837 .500 individu/l, diikuti perlakuan 200 $\left(\mathrm{ekor} / \mathrm{m}^{2}\right.$ ) sebanyak 41.267 .500 individu/l dan perlakuan $300\left(\mathrm{ekor} / \mathrm{m}^{2}\right)$ sebanyak 40.248.500 individu/l (Tabel 2).

Plankton termasuk mikroorganisme yang hidup nyamela yang-layang dalam air dan banyak sedikitnya komunitas plankton ditentukan oleh debet air yang masuk dari sumber air laut kedalam tambak melalui frekuensi pergantian air. Menurut Klemeneieet al. (2007) bahwa factor utama yang mempengaruhi struktur komunitas fitoplankton adalah perubahan kondisi lingkungan perairan pantai termasuk tambak yang disebabkan oleh pasang surut dan musim. Meskipun dalam penelitian ini pergantian air relative sama baik jumlah dan waktunya pada setiap petak perlakuan, namun demikian terdapat fenomena bahwa hanya beberapa spesies fitoplankton yang memiliki kelimpahan tinggi seperti Chlorophyta (alga hijau) dan Bacillariophyta (Diatome). Beberapa penelitian telah melaporkan bahwa genus ini umumnya sangat melimpah di tambak budidaya udang (Gracia dan Gracia, 1985; Utojo dan Pirza, 2009).

Menurut Nontji (2008) bahwa komponen fitoplankton dari kelas Bacillariophyceae atau diatom inibersifat kosmopolit, cepat berkembang di perairan dan paling umum dijumpai di laut, mulai dari wilayah pantai termasuk tambak hingga laut lepas. Indikator tambak yang baik untuk budidaya udang yaitu airnya berwarna cokelat muda karena pertumbuhan plankton yang didominasi oleh genus Naviculasp dan 
Nitzschiasp dari kelas Bacillariophyceae dan dengan kecerahan air $35 \mathrm{~cm}$ baik untuk dipertahankan (Poernomo, 1988). Kelimpahan genus plankton dalam perairan berfluktuatif bergantung pada musim, terdapat beberapa genus plankton yang melimpah pada musim kemarau, sedangkan genera lainnya melimpah pada musim hujan. Fluktuasi tersebut dipengaruhi oleh beberapa faktor, termasuk suhu, $\mathrm{pH}$, konsentrasi nutrien, cahaya, cuaca, penyakit, pemangsaan ikan dan zooplankton, kompetisi antara spesies, sertatoksin alga (Boyd, 1990).

Tabel 1. Komposisi genus, spesies dan kelimpahan fitoplankton pada setiap perlakuan selama periode pemeliharaan

\begin{tabular}{llccc}
\hline \multirow{2}{*}{ Genus } & \multicolumn{1}{c}{ Spesies } & \multicolumn{1}{c}{ Kelimpahan } \\
& Chlamydomonas & + & + & + \\
Chlorophyta (Alga hijau) & Tetraselmis & + & + & + \\
& Chlorella & + & + & + \\
& Oocytis & + & + & + \\
Cyanophyta (Alga biru hijau) & Oscillatoria & + & + & + \\
& Cylindropixis & - & - & - \\
& Microcyctis & - & + & - \\
Bacillariophyta (Diatome) & Coelosphaerium & + & - & - \\
& Nitzchia & + & + & + \\
& Amphora & + & + & + \\
& Chaetoceros & + & - & + \\
& Coscinodiscus & + & + & + \\
& Coscinodiscus & - & - & + \\
Dinoflagelata & Cyclotella & - & + & - \\
& Gyrodinium & + & + & + \\
Cryptophyta & Gymnodinium & - & + & + \\
\hline
\end{tabular}

Indeks keragaman mencerminkan tingkat keraga-man organisme dalam suatu ekosistem.Hasil analisis indeks keragaman ( $\left.\mathrm{H}^{\prime}\right)$, keseragaman (E) dan dominansi (C)setiap perlakuan tampak bervariasi antar ketiga perlakuan (Tabel 2). Indeks keragaman tertinggi berturut-turut pada perlakuan dengan kepadatan tebar $200 / \mathrm{m}^{2}$ $(0,35)$, diikuti perlakuan $300 / \mathrm{m}^{2}(0,22)$ dan perlakuan $100 / \mathrm{m}^{2}(0,11)$. Nilai indeks keragaman pada setiap perlakuan dapat dikategorikan rendah. Basmi (2000) menjelaskan bahwa apabila $\mathrm{H}^{\prime}<1$ maka stabilitas komunitas biota dinyatakan tidak stabil, apabila nilai $\mathrm{H}^{\prime}$ berkisar dari $1-3$ makastabilitas komunitas biota adalah moderat(sedang) dan apabila nilai $\mathrm{H}^{\prime}>3$ berartistabilitas komunitas biota bersangkutan dalam kondisi prima. Fenomena demikian dapat dinyatakan stabilitas komunitas plankton di tambak tersebut bersifat memiliki kondisi yang tidak stabil (Boyd, 2001). Kondisi komunitas plankton yang tidak stabil dapat dikatakan bahwa komunitas plankton sedang mengalami gangguan faktor lingkungan. Gangguan faktor lingkungan di tambak tersebut kemungkinan disebabkan oleh musim, pasang surut dan sumber air tambak serta limbah tambak intensif. Menurut Basmi (2000), masuknya limbah ke perairan pantai juga menjadi faktor yang sangat berpengaruh dan dapat menimbulkan tekanan terhadap lingkungan perairan tambak. 
Indeks keseragaman mencerminkan tingkat penyebaran organisme dalam suatu ekosistem.Indekskeseragaman (E) pada ketiga perlakuan berkisar antara 0,04-0,12 (Tabel 2). Nilai indeks keseragaman genus relatif merata atau dengan kata lain jumlah individu pada masing-masing genus relatif sama, namun demikian indeks keseragaman plankton tergolon grendah (Manguran, 1988;Basmi,2000). Ali (1994) mengemukakan bahwa apabila nilaiE $>0,75$ maka termasuk nilai keseragamannya tinggi atau baik, sedangkan apabila nilai $\mathrm{E}<0,75$ maka nilai keseragamannya rendah. Sedangkan indeks dominansi (C) tertinggi berturut-turut terdapat pada perlakuan $100 / \mathrm{m}^{2}(0,97)$, kemudian perlakuan $300 / \mathrm{m}^{2}(0,92)$ dan perlakuan $200 / \mathrm{m}^{2}$. Indeks dominansi yang mendekati nilai 0 , menunjukkan bahwa tidak terdapat spesies plankton tertentu yang mendominasi spesies lainnya. Hal tersebut mencerminkan bahwa struktur komunitas plankton dalam keadaan relatif stabil.

Meskipun demikian, hasil penelitian menunjukkan bahwa komunitas plankton pada ketiga perlakuan padat tebar sangat. Hal ini diduga terkait dengan perubahan habitat alami yang terjadi di lokasi tersebut. Wardoyo (1997) menyatakan bahwa faktor utama yang memengaruhi perubahan jumlah organisme, keragaman jenis dan dominansi adalah perusakan habitat alami seperti kon-versi lahan mangrove menjadi tambak, pencemaran kimiawi dan perubahan iklim. Hasil penelitian Lacerda et al., (2004) menunjukkan bahwa beberapa tekanan lingkungan (pencemaran industri, limbah rumah tangga dan kegiatan perikanan) terhadap estuarin Botafogo telah menyebabkan meningkatnya kelimpahan Diatom dan Dinoflagellata sehingga mendominasi perairan tersebut. Penelitian lain yang dilakukan oleh Osore et al., (2003) menunjukkan bahwa kekayaan spesies Copepoda di teluk Makupa, Mombasa, Kenya menurun seiring dengan meningkatnya limbah rumah tangga yang masuk ke perairan tersebut.

Tabel 2. Jumlah individu, genus dan spesies keragaman, keseragaman, dominansi plankton setiap

\begin{tabular}{lccc}
\hline \multirow{2}{*}{ Paramater } & \multicolumn{3}{c}{ Perlakuan } \\
\cline { 2 - 4 } & $100 \mathrm{ekor} / \mathrm{m}^{2}$ & $200 \mathrm{ekor} / \mathrm{m}^{2}$ & $300 \mathrm{ekor} / \mathrm{m}^{2}$ \\
\hline Jumlah individu (ind./L) & 41.837 .500 & 41.267 .500 & 40.248 .500 \\
Jumlah genus & 5 & 5 & 5 \\
Keragaman (H') & 0,11 & 0,35 & 0,22 \\
Keseragaman (E) & 0,04 & 0,12 & 0,08 \\
Dominansi(C) & 0,97 & 0,85 & 0,92 \\
\hline
\end{tabular}

\section{Kualitas Air}

Kualitas air sangat penting dalam menentukan kelayakan kehidupan udang. Parameter kualitas air yang diamati selama penelitian meliputi suhu, salinitas, derajat keasaman $(\mathrm{pH})$, oksigen terlarut (DO), alkalinitas, nitrit $\left(\mathrm{NO}_{2}{ }^{-}\right)$, nitrat $\left(\mathrm{NO}_{3}{ }^{-}\right)$, amoniak $\left(\mathrm{NH}_{3}\right)$, amonium $\left(\mathrm{NH}_{4}{ }^{+}\right)$, fosfat $\left(\mathrm{PO}_{4}{ }^{3-}\right)$, total bahan organik (BOT), total $\mathrm{N}$ dan $\mathrm{P}$. Parameter suhu, salinitas, $\mathrm{pH}$, alkalinitas, nitrat, nitrit dan fosfat relatif sama antar perlakuan, sedangkan parameter kecerahan, oksigenterlarut, $\mathrm{NH}_{3}, \mathrm{BOT}, \mathrm{N}$ dan $\mathrm{P}$ total berbeda antar perlakuan $(\mathrm{P}<0,05)$. Semua parameter kualitas air cenderung sesuai dengan kebutuhan dalam budidaya udang vaname (Babu et al., 2014). Meskipun demikian, parameter BOT dan alkalinitas relative tinggi (Boyd, 1998; Boyd and Queiroz 2001).Nilai rata-rata parameter kualitas air antar perlakuan padat tebar disajikan pada Tabel 3. 
Tabel 3. Nilai rata-rata parameter kualitas air antar perlakuan padat tebar selama pemeliharaan

\begin{tabular}{llccc}
\hline \multirow{2}{*}{ Variabel } & \multirow{2}{*}{ Satuan } & \multicolumn{3}{c}{ Nilai rata-rata variabel dan uji beda } \\
\cline { 3 - 5 } & & $100\left(\right.$ ekor/m $\left.\mathrm{m}^{2}\right)$ & $200\left(\mathrm{ekor} / \mathrm{m}^{2}\right)$ & $300\left(\mathrm{ekor} / \mathrm{m}^{2}\right)$ \\
\hline Suhu & ${ }^{0} \mathrm{C}$ & $29,2 \pm 0,4^{\mathrm{a}}$ & $29,6 \pm 0,3^{\mathrm{a}}$ & $28,7 \pm 0,4^{\mathrm{a}}$ \\
Kecerahan & $\mathrm{cm}$ & $39,6 \pm 0,1^{\mathrm{a}}$ & $38,07 \pm 0,8^{\mathrm{b}}$ & $38,6 \pm 0,5^{\mathrm{ab}}$ \\
Salinitas & $\mathrm{ppt}$ & $22,1 \pm 2,7^{\mathrm{a}}$ & $25,1 \pm 1,0^{\mathrm{a}}$ & $24,8 \pm 1,4^{\mathrm{a}}$ \\
$\mathrm{pH}$ & $\mathrm{unit}$ & $7,9 \pm 0,0^{\mathrm{a}}$ & $7,9 \pm 0,0^{\mathrm{a}}$ & $7,9 \pm 0,0^{\mathrm{a}}$ \\
$\mathrm{DO}$ & $\mathrm{mg} / \mathrm{L}$ & $4,51 \pm 0,1^{\mathrm{a}}$ & $4,2 \pm 0,1^{\mathrm{b}}$ & $4,2 \pm 0,1^{\mathrm{b}}$ \\
$\mathrm{NO}_{2}$ & $\mathrm{mg} / \mathrm{L}$ & $1,7 \pm 0,3^{\mathrm{a}}$ & $1,9 \pm 0,1^{\mathrm{a}}$ & $1,3 \pm 0,5^{\mathrm{a}}$ \\
$\mathrm{NO}_{3}$ & $\mathrm{mg} / \mathrm{L}$ & $2,4 \pm 0,4^{\mathrm{a}}$ & $1,5 \pm 0,2^{\mathrm{a}}$ & $2,3 \pm 0,6^{\mathrm{a}}$ \\
$\mathrm{NH}_{3}$ & $\mathrm{mg} / \mathrm{L}$ & $0,5 \pm 0,04^{\mathrm{a}}$ & $0,7 \pm 0,02^{\mathrm{b}}$ & $0,8 \pm 0,03^{\mathrm{b}}$ \\
$\mathrm{PO}_{4}$ & $\mathrm{mg} / \mathrm{L}$ & $11,8 \pm 0,6^{\mathrm{a}}$ & $10,9 \pm 1,5^{\mathrm{a}}$ & $13,6 \pm 2,4^{\mathrm{a}}$ \\
$\mathrm{BOT}^{\mathrm{CO}}$ & $\mathrm{mg} / \mathrm{L}$ & $185,2 \pm 24,4^{\mathrm{a}}$ & $188,8 \pm 9,6^{\mathrm{a}}$ & $248,2 \pm 18,8^{\mathrm{b}}$ \\
$\mathrm{CO}_{2}$ & $\mathrm{mg} / \mathrm{L}$ & $36,8 \pm 3,3^{\mathrm{a}}$ & $39,1 \pm 9,4^{\mathrm{a}}$ & $38,6 \pm 3,4^{\mathrm{a}}$ \\
$\mathrm{Alkalinitas}_{\mathrm{N}}$ & $\mathrm{mg} / \mathrm{L}$ & $179,7 \pm 5,6^{\mathrm{a}}$ & $177,0 \pm 8,6^{\mathrm{a}}$ & $176,0 \pm 6,9^{\mathrm{a}}$ \\
$\mathrm{P}_{\text {Total }}$ & $\mathrm{mg} / \mathrm{L}$ & $0,10 \pm 0,0^{\mathrm{a}}$ & $0,12 \pm 0,0^{\mathrm{b}}$ & $0,12 \pm 0,0^{\mathrm{b}}$ \\
P Total & $\mathrm{mg} / \mathrm{L}$ & $17,3 \pm 0,03^{\mathrm{a}}$ & $17,9 \pm 0,0^{\mathrm{b}}$ & $18,4 \pm 0,0^{\mathrm{c}}$ \\
\hline
\end{tabular}

Huruf yang berbeda pada baris yang sama menunjukkan berbeda nyata pada selang kepercayaan $95 \%$

\section{Kesimpulan}

Terdapat 5 genera dan 18 spesies yang teridentifikasi dalam tambak lahan pasir. Kelompok fitoplankton yang melimpah pada tambak udang dengan kepadatan berbeda adalah kelas Chlorophyta dan Bacillariophyta. Indeks keragaman dan keseragaman relatif rendah, sedangkan indeks dominansi plankton relatif stabil.

\section{Daftar Pustaka}

Ali, I.M. 1994. Struktur Komunitas Ikan dan AspekBiologi Ikan yang Dominan di DanauSidengreng, SulawasiSelatan. Tesis. Fakultas Perikanan Institut Pertanian Bogor, $130 \mathrm{hlm}$.

APHA. (2005). Standard Method for the Examination of Water and Wastewater 21 th ed. Washington DC: American Public Health.

Babu, D., Ravuru and J.N. Mude. 2014a. Effect of Densitity on Growth and Production of Litopenaeus vannamei of Brackish Water Culture System in Summer Season with Artificial Diet in Prakasam District, India. American International Journal of Research in Formal, Applied \& Natural Sciences, 5(1). pp 10 - 13.

Barnes, R.S.K., and K. Mann. 1991.Fundamental of Aquatic Ecosystem(Prologue). Blackwell Sci. PublisherOxford, 226 p.

Basmi, H.J. 2000. Planktonologi: Plankton sebagai Bio indicator Kualitas Perairan. Fakultas Perikanan dan Ilmu Kelautan. Institut Pertanian Bogor(IPB), Bogor. 60 hal.

Botes, L. 2003. Phytoplankton Identification Catalogue.Globallast Monograph Series No. 7. Programme Coordination Unit Global Ballast Water Management Programme International Marine Organization. London. 77 p.

Boyd, C.E. 1998. Water Quality for Pond Aquaculture. Department of Fisheries and Allied Aquacultures. Auburn University. Alabama. 39p. 
Boyd C.E. and J.F. Queiroz, 2001. Nitrogen, Phosphorus Loads Vary by System USEPA Should Consider System Variables in Setting New Effluent Rules.The Advocate.

Gracia, W.U., and R.U., Gracia. 1985. Prawnfarming. Manila. 163 pp.

Klemeneie, A.K., Vrhovsek, D. and SmolarZ.N. 2007. Microplanktonic andmicrobenthic algal assemblages in thecoastal brackish Lake Fiesa and theDragonja Estuary (Slovenia) Nat.Croat. 16(1):63-78 pp.

Lacerda S. R., Koening M. L., Neumann-Leitao S. dan Flo-res-Montes M. J., 2004. Phytoplankton nyctemeral variation at a tropical river estuary (ItamaracaPernambuco - Brazil). Brazillian Journal of Biology 64 (1), pp. 81-94.

Manguran E. A., 1988. Ecology Diversity and It's Measure-ment. Precenton University. New Jersey, pp. 179.

Newell, G.E. and R.C. Newell. 1977. Marine Plankton. A Practical Guide 5 th.Edition Hutchinson of London. 244 p.

Nontji, A. 2002. Laut Nusantara. Djambatan, Jakarta.

Odum, E.P. 1993. Dasar-dasar Ekologi. Edisi ketiga. Penerjemah: Samingan, T. Gadjah Mada University Press. Yogyakarta.

Osore M. K. W., F. Fiers dan M. H. Daro, 2003. Copepod composition, abundance and diversity in Makupa creek, Mombasa, Kenya. Western Indian Journal of Marine Scienc-es 2 (1), pp. 65-73.

Poernomo, A. 1988. Pembuatan Tambak Udang Indonesia. Seri Pengembangan No. 7, 1988. Departemen Pertanian. Badan Penelitian dan Pengembangan Pertanian. Balai Penelitian Perikanan Budidaya Pantai, Maros. 30 hal.

Poernomo, A., 1997. Petunjuk pelaksanaan pengembangan budidaya udang ramah lingkungan. Ditjen Perikanan.

Utojo dan A.M. Pirzan. 2009. Kondisi plankton di tambak bandeng dangaram Kabupaten Jeneponto,Sulawesi Selatan. Dalam Jumanto, Dwiyitno, Chasanah, Heruwati, E.S.,Irianto, H.E., Saksono, H., Iwan Yusuf,B. L., Basmal, J., Murniati, Murwantoko, Probosunu, N., Rosmawaty, P., Rustadi dan Ustadi(eds.). Prosiding Seminar Nasional Tahun VI Hasil Penelitian Perikanan dan Kelautan Tahun 2009. Jurusan Perikanan dan Kelautan Fakultas Pertanian, Universitas Gadjah Mada,Yogyakarta. Hal.1-8.

Yamaji, I., 1976. Illustration of the marine plankton of Japan. Hoikusha Publishing Co. Ltd., Osaka, Japan,369 pp.

Wardoyo J., 1997. Biodiversitas sumberdaya perikanan laut peranannya dalam pengelolaan terpadu wilayah pantai. In: Mallawa A, R Syam, N Naamin, S Nurhakim, E S Kartami-hardja, A Poernomo dan Rachmansyah (Eds). Prosiding Sim-posiumPerikanan Indonesia II, Ujung Pandang 2-3 Desem-ber 1997, pp. 136-141. 